\title{
Multivariate techniques in the determination of genetic diversity in pest-resistant mini tomato genotypes
}

\section{Gabriel M Maciel $^{1}$; Joicy Vitória M Peixoto ${ }^{1}$; Jaíne Priscila R Rocha ${ }^{1}$; Rafaela S Almeida ${ }^{1}$; Camila S Oliveira ; Thiago Fellipe N Mendonça ${ }^{1}$}

${ }^{1}$ Universidade Federal de Uberlandia (UFU), Monte Carmelo-MG, Brazil; gabrielmaciel@ufu.br; joicyvmpeixoto@yahoo.com.br; jainepriscila07@hotmail.com; rafaelaalmeida94@hotmail.com; camilaagroufu@gmail.com; thiagofellipe@live.com

\begin{abstract}
The objective of this study was to compare methods of multivariate analysis on the evaluation of genetic diversity of mini tomato and to identify promising genotypes with resistance to pests. The experiment was conducted at the Vegetable Experiment Station of the Universidade Federal de Uberlândia, Monte Carmelo campus, from April 2013 to November 2016. The experimental design was a randomized complete block design with 16 treatments and four replications totaling 64 plots, and each plot represented by five plants. Sixteen genotypes were characterized, 12 from the $\mathrm{F}_{2} \mathrm{RC}_{1}$ generation, obtained through the interspecific crossing between the wild access LA-716 (Solanum pennellii) and pre-commercial lines of mini tomato (UFU-73 and UFU-2) (Solanum lycopersicum) and the UFU-2 lines. The content of acyl sugar, the amount of glandular trichomes (types I, IV, VI and VII), twospotted spider mite and whitefly resistance were evaluated. We concluded that there exist genetic variability between the genotypes. The number of groups formed by the canonical variated analysis was higher (four groups) than that obtained by the Tocher method (three groups) and UPGMA (three groups), demonstrating a greater discrimination power. The Tocher and UPGMA methods were consistent in the analysis of the genetic divergence in pest resistant germplasm of tomato, with the acyl sugar content being the most important variable. Genotype UFU-73- $\mathrm{F}_{2} \mathrm{RC}_{1} \# 11$ is resistant to pest attack, while the other studied lines have intermediate resistance.
\end{abstract}

Keywords: Solanum pennellii, Solanum lycopersicum, acyl sugar, genetic variability.

\section{RESUMO}

Técnicas multivariadas na determinação da diversidade genética em genótipos de minitomate resistentes a pragas

A pesquisa foi realizada com o objetivo de comparar diferentes métodos de análise multivariada na avaliação da diversidade genética em minitomate e identificar genótipos promissores com resistência a pragas. O experimento foi conduzido na Estação Experimental de Hortaliças da Universidade Federal de Uberlândia, campus Monte Carmelo, no período de abril de 2013 a novembro de 2016. O delineamento experimental foi em blocos casualizados com 16 tratamentos e quatro repetições totalizando 64 parcelas, sendo cada parcela representada por cinco plantas. Foram caracterizados 16 genótipos, sendo 12 provenientes da geração $\mathrm{F}_{2} \mathrm{RC}_{1}$, obtidos por meio do cruzamento interespecífico entre o acesso selvagem LA-716 (Solanum pennellii) versus linhagens pré-comerciais de minitomate (UFU-73 e UFU-2) (Solanum lycopersicum) e as linhagens UFU-2. Avaliou-se o teor de acilaçúcar, a quantidade de tricomas glandulares (tipos I, IV, VI e VII), a resistência ao ácaro e à mosca branca. Pode-se concluir que existe variabilidade genética entre os genótipos. $\mathrm{O}$ número de grupos formados pelo método de variáveis canônicas foi superior (quatro grupos) ao obtido pelo método de Tocher (três grupos) e UPGMA (três grupos), demonstrando maior poder de discriminação. Os métodos de Tocher e UPGMA foram coerentes quanto à análise da divergência genética em germoplasma de tomateiro resistente a pragas, sendo o teor de acilaçúcar a variável de maior importância. O genótipo UFU-73- $\mathrm{F}_{2} \mathrm{RC}_{1}$ \# 11 é resistente ao ataque de pragas, enquanto as outras linhagens estudadas apresentam resistência intermediária.

Palavras-chave: Solanum pennellii, Solanum lycopersicum, acilaçúcar, variabilidade genética.

Received on November 3, 2017; accepted on March 14, 2018

$\mathrm{T}$ he tomato crop (Solanum lycopersicum) stood out in recent years as an important agrarian activity in Brazil and in the world. In 2016, the area destined for tomato production in Brazil surpassed 57,000 hectares, with an estimated increase of $8 \%$ in 2017 , surpassing 62,000 hectares (IBGE, 2017). In this context, the cultivation of mini tomato has also increased due to its productivity and particularities related to the fruit such as reduced size, rounded and elongated shapes, various colors and high soluble solids content among others (Preczenhak et al., 2014; Maciel et al., 2015, 2016).

Despite this relevance, the tomato cultivation is considered a high risk activity due to a great variety of pests that occur during its cultivation. Among the main arthropod pests, the whitefly (Bemisia tabaci) and the twospotted spider mite (Tetranychus urticae) causes damage to the crop productivity (Neiva et al., 2013; Maciel et al., 2017). An alternative to control these arthropods is using genotypes with a 
broad spectrum of pest resistance (Maluf et al., 2010). It is possible to increase the genetic variability in tomatoes aiming at resistance to pests in breeding programs and to increase the number of accesses available in germplasm bank (Neiva et al., 2013; Maciel \& Silva, 2014; Maciel et al., 2017). Gruber (2017) reported that one of the priorities in tomato breeding programs should be to obtain pest-resistant plants. However, we have not found reports of the applicability of multivariate analysis in germplasm banks of tomato with different levels of resistance to pests.

The variability among genotypes can be estimated by measures of genetic dissimilarity, standing out the Mahalanobis distance $\left(\mathrm{D}_{\mathrm{ii}}^{2}\right)$. This technique considers residual variances and covariance between quantitative characters (Cruz et al., 2012). To characterize this divergence, the Tocher's optimization method and the hierarchical method Unweighted Pair-Group Method Using Arithmetic Averages (UPGMA) are routinely used in tomato (Mattedi et al., 2014; Araújo et al., 2016). However, there is no consensus regarding the use of these techniques in mini-tomato germplasm whose genetic variability refers to the different levels of resistance to pests. The studies comparing methods of multivariate analysis in mini-tomato resistant to pests are scarce.

Considering the importance of tomato crops in national and international context, the evaluation of genetic diversity of mini tomato populations for pest resistance will provide the knowledge of the best combinations to obtain segregating or hybrid generations, allowing the obtention of superior genotypes. Then, the objective of this study was to compare methods of multivariate analysis on the evaluation of genetic diversity of mini tomato and to identify promising pest resistant genotypes.

\section{MATERIAL AND METHODS}

The experiment was conducted at the Experimental Station of Vegetables

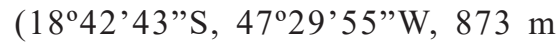

altitude) and at LAGEN (Genetic Resources Laboratory) of Universidade Federal de Uberlândia (UFU), Campus Monte Carmelo, from April 2013 to November 2016.

Sixteen genotypes were characterized: twelve $\mathrm{F}_{2} \mathrm{RC}_{1}$ genotypes from the interspecific cross between wild access LA-716 (S. pennellii) versus pre-commercial lines of mini tomato (UFU-73 and UFU-2) (S. lycopersicum) followed by backcrossing and selffertilization. These lines from free market were chosen because of their desirable agronomic characteristics as high soluble solids content.

Inbred lines UFU-2 have indeterminate growth habit (homozygous dominant, SP/SP), fruits with $11^{\circ}$ Brix soluble solids contents, red, average weight of $15 \mathrm{~g}$ and susceptible to pests. The mini-tomato lines UFU-73 have determinate growth habit (homozygous recessive, $\mathrm{sp} / \mathrm{sp}$ ), fruits with $10^{\circ} \mathrm{Brix}$ soluble solids content, yellow, average weight of $18 \mathrm{~g}$ and susceptible to pests. The access LA-716 is rich in the allelochemical acyl sugar, capable of providing broad spectrum of resistance to pests in tomato and the commercial cultivar Santa Clara (susceptible to pests).

Genotypes were sown on May 2016, using 200-cell polystyrene trays filled with commercial coconut-based substrate. After 35 days of sowing, the seedlings were transplanted in $5 \mathrm{~L}$ pots filled with the same substrate used to produce them.

The experiment was conducted in randomized complete block design, with four repetitions totaling 64 plots, each plot represented by 5 plants, totaling 320 plants in the experiment. The plants were conducted in an arctype greenhouse, with dimensions $7 \times 21 \mathrm{~m}$ and 4 meters ceiling height, covered with 150-micron transparent polyethylene film and white anti-aphid screen side curtains. The same plants were used to quantify the levels of acyl sugar, foliar trichrome, twospotted spider mite and whitefly repellency.

After 75 days of sowing, a sample composed of 6 leaf discs (equivalent to $4.2 \mathrm{~cm}^{2}$ ) was collected in each of the five plants of the plot. The discs were collected from leaflets present in the upper third of the plants and packed in test tubes. The extraction and quantification of the allelochemical acyl sugar followed the methodology described by Resende et al. (2002) and adapted by Maciel \& Silva (2014).

Glandular trichomes (types I, IV, VI and VII) were quantified according to the methodology of Glas et al. (2012), in the periods of $30,45,60,75$ and 90 days after sowing. Five young and expanded leaflets were collected from the upper third of each plant and the number of epidermal glandular trichomes per $\mathrm{cm}^{2}$ was evaluated on the abaxial and adaxial surfaces. Trichomes were quantified with a stereomicroscope (40x), with a micrometric scale of $1 \mathrm{~cm}^{2}$ area.

The twospotted spider mite resistance was quantified according to Weston \& Snyder's (1990) repellency test, measuring the distances covered by arthropods on the leaflet surfaces of the genotypes at 5,10,15 and 20 minutes. The test was done with the placement of five twospotted spider mites on a thumbtack attached to the center of each leaflet.

The presence of whitefly was verified according to the methodology described by Maluf et al. (2010). After 90 days of sowing, the number of eggs and nymphs per $\mathrm{cm}^{2}$ of leaf area were quantified with the aid of a stereomicroscope (40x). Five leaflets of the upper third of the plant were evaluated by each genotype. For counting the number of adults, a mirror was used to visualize the insects before the escape to the abaxial part of each leaflet.

The data were submitted to multivariate analysis with the objective of determining the genetic dissimilarity between the genotypes. The dissimilarity matrix was obtained by Mahalanobis distance $\left(\mathrm{D}_{\mathrm{ii}}^{2}\right)$. From Mahalanobis distance matrix, the genetic divergence was represented by a dendrogram obtained by the hierarchical method Unweighted Pair-Group Method Using Arithmetic Averages (UPGMA), validated by the cophenetic correlation coefficient (CCC) with Mantel's test (1967). Tocher's optimization method was also used to cluster the genotypes. 
The relative contribution of the quantitative traits was calculated according to Singh (1981). For the analysis by canonical variables, the genetic divergence was demonstrated by the dispersion of the scores in graphs, with the axes represented by the first canonical variables. All analyzes were performed using the software Genes v. 2015.5.0 (Cruz, 2013).

\section{RESULTS AND DISCUSSION}

The genetic dissimilarity measures (Table 1), estimated from the generalized distance of Mahalanobis $\left(\mathrm{D}^{2}\right)$, ranged from 44.02 to 53257.93. This implies the presence of genetic divergence among the studied genotypes (Azevedo et al., 2015). We observed that $87.5 \%$ of the studied genotypes presented greater divergence when compared to $S$. pennellii genotype. However, the Santa Clara genotype presented a shorter distance in relation to the wild access.

For UPGMA dendrogram, the value of the cophenetic correlation coefficient (CCC) was 0.77 with $29.64 \%$ of distortion, which shows an adequate relation between the matrix distance and the dendrogram produced.

When a cut considering $35 \%$ of dissimilarity was made, we observed the formation of three clusters (Figure 1). The first group consisted of $81.25 \%$ of the genotypes under study (UFU-22F2RC1\#1; UFU-22-F2RC1\#2; UFU-22F2RC1\#3; UFU-22-F2RC1\#4; UFU-22F2RC1\#5; UFU-22-F2RC1\#6; UFU-22F2RC1\#7; UFU-22-F2RC1\#8; UFU22-F2RC1\#9; UFU-22-F2RC1\#10; UFU-73-F2RC1\#12; UFU-73-2-310-1 and UFU-F4-2-2-2). The Santa Clara genotype, characterized as being susceptible to pest attack, formed an isolated group. The third cluster consisted of the UFU-73-F2RC1\#11 genotype and the wild-access $S$. pennellii genotype characterized by being tolerant to insect attack. Using this same method, Lucatti et al. (2013), evaluating the genetic diversity of 35 accessions of tomato on resistance to $B$. tabaci, detected divergence between them, observing the formation of two

Table 1. Estimates of the nearest and further distance of 16 mini tomato genotypes, based on the Mahalanobis distance $\left(\mathrm{D}^{2}\right)$. Monte Carmelo, UFU, 2013-2016.

\begin{tabular}{lcccc}
\hline Genotypes $^{1}$ & Smaller D $^{\mathbf{2}}$ & Closer & Higher D $^{2}$ & Less close \\
\hline 1 & 72.80 & 8 & 24022.13 & 16 \\
2 & 13.94 & 6 & 31588.91 & 16 \\
3 & 115.06 & 5 & 21355.78 & 16 \\
4 & 44.02 & 5 & 20684.83 & 16 \\
5 & 44.02 & 4 & 19998.79 & 16 \\
6 & 68.84 & 8 & 28198.82 & 16 \\
7 & 142.27 & 9 & 16639.61 & 16 \\
8 & 68.84 & 6 & 26207.23 & 16 \\
9 & 142.27 & 7 & 15045.47 & 16 \\
10 & 194.62 & 7 & 16505.18 & 16 \\
11 & 3318.14 & 9 & 26882.11 & 13 \\
12 & 123.80 & 5 & 17826.78 & 16 \\
13 & 2862.08 & 15 & 53257.93 & 16 \\
14 & 141.82 & 8 & 26482.89 & 16 \\
15 & 238.45 & 6 & 31774.25 & 16 \\
16 & 53257.93 & 11 & 5611.72 & 13 \\
\hline
\end{tabular}

${ }^{1} 1=$ UFU-22-F2RC1\#1; $2=$ UFU-22-F2RC1\#2; 3=UFU-22-F2RC1\#3; 4=UFU-22-F2RC1\#4; $5=\mathrm{UFU}-22-\mathrm{F} 2 \mathrm{RC} 1 \# 5 ; 6=\mathrm{UFU}-22-\mathrm{F} 2 \mathrm{RC} 1 \# 6 ; 7=\mathrm{UFU}-22-\mathrm{F} 2 \mathrm{RC} 1 \# 7 ; 8=\mathrm{UFU}-22-\mathrm{F} 2 \mathrm{RC} 1 \# 8$; $9=$ UFU-22-F2RC1\#9; $10=$ UFU-22-F2RC1\#10; 11= UFU-73-F2RC1\#11; $12=$ UFU-73F2RC1\#12; 13= Santa Clara; 14= UFU-73-2-3-10-1; 15= UFU-F4-2-2-2; 16= Solanum pennellii. groups.

The clustering of the 16 mini tomato genotypes by Tocher's optimization method allowed the formation of three groups: I: Inbred lines UFU-22F2RC1\#4, UFU-22-F2RC1\#5, UFU-22F2RC1\#3, UFU-73-F2RC1\#12, UFU22-F2RC1\#7, UFU-22-F2RC1\#9, UFU22-F2RC1\#10, UFU-22-F2RC1\#1, UFU-73-2-3-10-1, UFU-22-F2RC1\#8, UFU-22-F2RC1\#6, UFU-F4-2-2-2 and UFU-22-F2RC1\#2; II: Santa Clara genotype, III: UFU-73-F2RC1\#11 and S. pennellii (Table 2).

The Tocher's method was similar to the UPGMA method. The group I in both methods had the highest number of genotypes $(87.5 \%)$. The genotype UFU-73-F2RC1\#11 was allocated in the same group as the wild-type $S$. pennellii, representing the genotype with the highest tolerance to pest attack. The second group was formed by the Santa Clara hybrid, susceptible to pest attack. In contrast, the group III was represented by genotypes with intermediate level of resistance.

Using Tocher and UPGMA clustering methods, Luz et al. (2016) in a genetic diversity study of 53 tomato hybrids for industrial processing, and Faria et al. (2012) evaluating genetic divergence in peppers, reported predominance of genotypes in one group and formation of groups with only one genotype. The results observed in the present study corroborate with those obtained by these authors.

The importance of the use of analysis of characters stands out for studying the total available variation of the genotypes based on the evaluated characteristics. Based on the criteria proposed by Singh (1981), in terms of the relative contribution of each character to the genetic divergence (Table 3), we verified that the most important characteristics for discrimination of the genotypes were: acyl sugar content $(37.05 \%)$, number of nymphs per plant $(12.48 \%)$ and number of eggs per plant (12.32\%), and the characters of lower contribution were the distance covered by the twospotted spider mite during five minutes $(0.05 \%)$ and the counting of trichomes with thirty days $(0.07 \%)$.

In the analysis of the importance 
of characters obtained by means of Canonic Variables, the acyl sugar content was the one that contributed the most to the genetic divergence among

the accessions. This result is relevant, because it discriminates the existence of wide variability of the degree of resistance between the accesses,

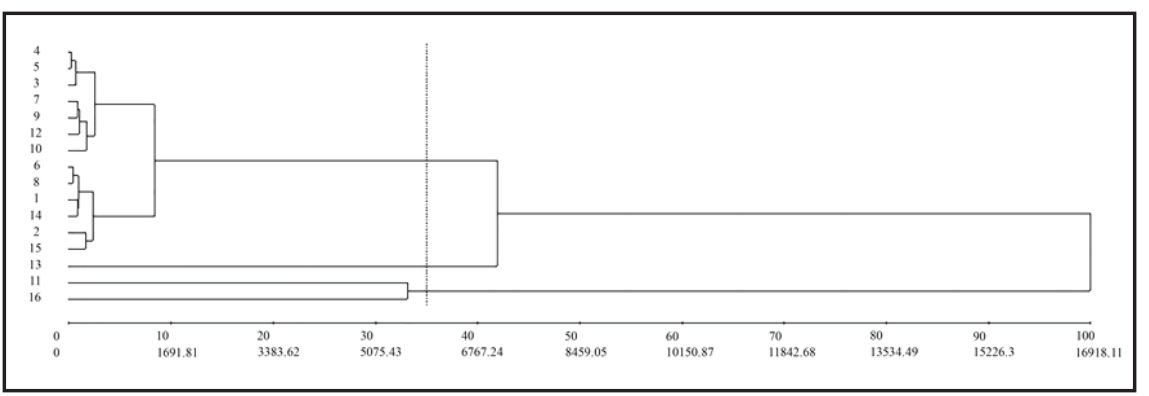

Figure 1. Unweighted Pair-Group Method Using Arithmetic Averages (UPGMA) dendrogram of 16 mini tomato genotypes obtained with the Mahalanobis distance generated with thirteen characters. $1=\mathrm{UFU}-22-\mathrm{F} 2 \mathrm{RC} 1 \# 1 ; 2=\mathrm{UFU}-22-\mathrm{F} 2 \mathrm{RC} 1 \# 2 ; 3=\mathrm{UFU}-22-\mathrm{F} 2 \mathrm{RC} 1 \# 3$; 4=UFU-22F2RC1\#4; 5= UFU-22-F2RC1\#5; 6= UFU-22-F2RC1\#6; 7= UFU-22-F2RC1\#7; 8= UFU22-F2RC1\#8; 9= UFU-22-F2RC1\#9; 10= UFU-22-F2RC1\#10; 11= UFU-73-F2RC1\#11; 12=UFU-73-F2RC1\#12; 13= Santa Clara; 14= UFU-73-2-3-10-1; 15=UFU-F4-2-2-2; 16= Solanum pennellii. Monte Carmelo, UFU, 2013-2016.

Table 2. Mini tomato genotypes clustered by Tocher's optimization method estimated with Mahalanobis distance. Monte Carmelo, UFU, 2013-2016.

\begin{tabular}{|c|c|}
\hline Group & Genotypes \\
\hline $\mathrm{I}$ & $\begin{array}{l}\text { UFU-22-F2RC1\#4, UFU-22-F2RC1\#5, UFU-22-F2RC1\#3, } \\
\text { UFU-73-F2RC1\#12, UFU-22-F2RC1\#7, UFU-22-F2RC1\#9, } \\
\text { UFU-22-F2RC1\#10, UFU-22-F2RC1\#1, UFU-73-2-3-10-1, } \\
\text { UFU-22-F2RC1\#8, UFU-22-F2RC1\#6, UFU-F4-2-2-2 e UFU- } \\
\text { 22-F2RC1\#2 }\end{array}$ \\
\hline II & Santa Clara \\
\hline III & UFU-73-F2RC1\#11 and Solanum pennellii \\
\hline
\end{tabular}

Table 3. Relative contribution (\%) of characteristics for genetic divergence in mini tomato genotypes, estimated by the method proposed by Singh (1981). Monte Carmelo, UFU, 2013-2016.

\begin{tabular}{|c|c|}
\hline Variable & S.j (\%) \\
\hline Acyl sugar (nmol/cm² of leaf area) & 37.05 \\
\hline Number of nymphs & 12.48 \\
\hline Number of eggs & 12.32 \\
\hline Number of trichomes $(90 \mathrm{DAS})^{1}$ & 8.90 \\
\hline Number of adult insects & 8.79 \\
\hline Number of trichomes $(60 \mathrm{DAS})^{1}$ & 7.89 \\
\hline DP twospotted spider mite $(15 \text { minutes })^{2}$ & 6.71 \\
\hline DP twospotted spider mite $(10 \text { minutes })^{2}$ & 3.92 \\
\hline Number of trichomes (75 DAS $)^{1}$ & 1.08 \\
\hline Number of trichomes $(45 \mathrm{DAS})^{1}$ & 0.49 \\
\hline DP twospotted spider mite $(10 \text { minutes })^{2}$ & 0.27 \\
\hline Number of trichomes $(30 \mathrm{DAS})^{1}$ & 0.07 \\
\hline DP twospotted spider mite $(15 \text { minutes })^{2}$ & 0.03 \\
\hline
\end{tabular}

${ }^{1} \mathrm{DAS}=$ days after sowing; ${ }^{2} \mathrm{DP}=$ distance covered by the twospotted spider mite. allowing the selection of accesses with greater potential for resistance to pests.

The relative importance of canonical variables was measured by the percentage of their eigenvalues in relation to the total eigenvalues. The values of the canonical variables analysis, obtained by the correlation matrix of the evaluated characters, revealed that the first two canonical variables were sufficient to explain $98.74 \%$ of the variation observed. The first variable absorbed $96.06 \%$ of the variation obtained by the characteristics of greater contribution: the acyl sugar content. The second canonical variable represented $2.68 \%$ of the variation obtained based on the variables of greatest contribution: twospotted spider mite covering during fifteen minutes.

Silva et al. (2016), evaluating the F2 generation, from interspecific crossing between $S$. lycopersicum (TOM-684) and S. galapagense (LA1401), observed that genotypes selected for high density of type IV glandular trichomes presented resistance to the caterpillar Helicoverpa armigera. These trichomes are associated with the production of acyl sugar. Silva et al. (2017) and Maciel et al. (2018a) also observed that tomato genotypes with higher acyl sugar content presented resistance to Liriomyza trifolii and Spider mite, respectively.

For the satisfactory interpretation of the variability found among the genotypes it is necessary that the first two canonical variables presented a minimum estimate of $80 \%$ of the total variation contained in the mentioned character (Cruz et al., 2012). In this study the first two canonical variables explained more than $80 \%$ of the total variance of characters analyzed $(98.74 \%)$. In this way the variability manifested among the genotypes can be explained by means of the dispersion graph (Figure 2). By the scatter plot method, four groups were formed. The Santa Clara and S. pennelli genotypes formed isolated and distant groups. The genotype UFU-73-F2RC1\#11 formed an isolated group, being between $S$. pennelli and the group formed by the other genotypes. In this way the scatter plot method differed from the other 


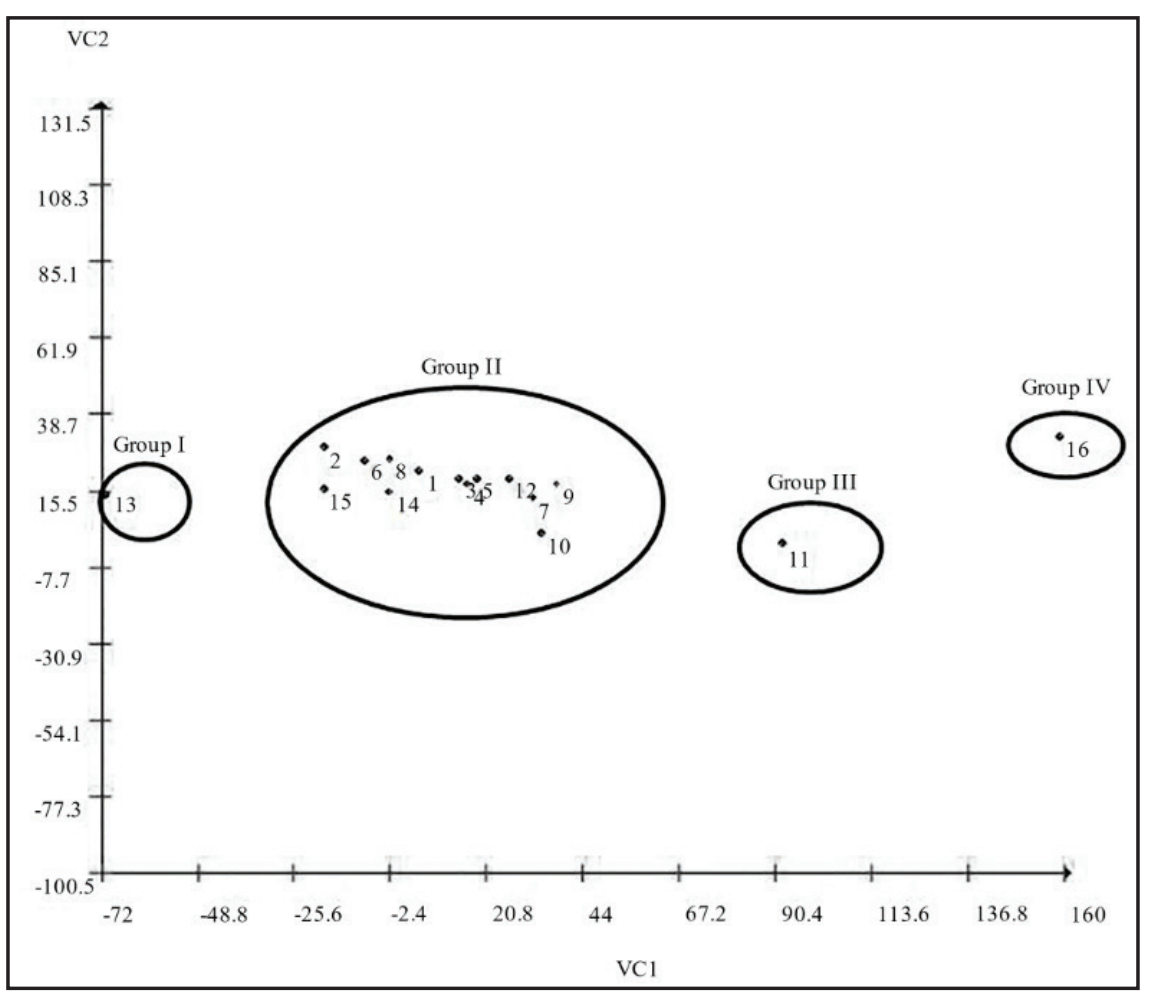

Figure 2. Dispersion graph of 16 mini tomato genotypes in relation to the scores of the first two canonical variables, VC1 (96.06\%) and VC2 (2.68\%). 1=UFU-22-F2RC1\#1; $2=$ UFU-22-F2RC1\#2; $3=$ UFU-22-F2RC1\#3; 4=UFU-22-F2RC1\#4; $5=$ UFU-22-F2RC1\#5; $6=$ UFU-22-F2RC1\#6; 7= UFU-22-F2RC1\#7; 8= UFU-22-F2RC1\#8; 9= UFU-22-F2RC1\#9; $10=$ UFU-22-F2RC1\#10; 11= UFU-73-F2RC1\#11; 12= UFU-73-F2RC1\#12;13= Santa Clara; 14= UFU-73-2-3-10-1; 15= UFU-F4-2-2-2; 16= Solanum pennellii. Monte Carmelo, UFU, 2013-2016.

analyzed methods, due to the formation of a larger number of groups.

The formation of coincident groups, through the use of complementary methods of multivariate analysis, is also described in pepper (Negreiros \& Miqueloni, 2013), passion fruit (Paiva et al., 2014), tomato (Luz et al., 2016; Amaral Júnior et al., 2017; Maciel et al., 2018b), which shows consistency of similarity results in the groups composition. The results obtained in the present study corroborate those found by these authors.

The application of the UPGMA hierarchical method, Tocher's optimization and canonical variables allowed to conclude the existence of genetic variability among the genotypes. The number of groups formed by the canonical variables method was higher (four groups) than that obtained by the Tocher method (three groups) and UPGMA (three groups), demonstrating a greater discriminating power. This allows the identification of more groups containing similar accesses. In addition, there was consistency between Tocher and UPGMA methods for the analysis of genetic divergence in pest-resistant tomato germplasm, with the most important variable being the acyl sugar content. Genotype UFU-73-F2RC1 \# 11 is resistant to pest attack, while the other lines studied have intermediate resistance.

\section{REFERENCES} M; VIANA, AP; RODRIGUES, R. 2017. Prospecting of tomato hybrids for table and industry via mixed modeling and multivariate analysis. Horticultura Brasileira 35:20-25.

ARAÚJO, JC; TELHADO, SFP; SAKAI, RH; LEDO, CAS; MELO, PCT. 2016. Univariate and multivariate procedures for agronomic evaluation of organically grown tomato cultivars. Horticultura Brasileira 34: 374-380.

AZEVEDO, AM; ANDRADE JUNIOR, VC; FIGUEIREDO, JA; PEDROSA, EC; VIANNA, DJS; LEMOS, VT; NEIVA, IP.
AMARAL JÚNIOR, AT; GRAÇA, AJP; VIVAS,
2015. Divergência genética e importância de caracteres em genótipos de batata-doce visando a produção de silagem. Revista Brasileira de Ciências Agrárias. 10: 479-484.

CRUZ, CD. 2013. GENES: a software package for analysis in experimental statistics and quantitative genetics. Acta Scientiarum 35: 271-276.

CRUZ, CD; REGAZZI, AJ; CARNEIRO, PCS. 2012. Modelos biométricos aplicados ao melhoramento genético. Viçosa: UFV. 514p.

FARIA, PN; CECON, PR; SILVA, AR; FINGER, FL; SILVA, FF; CRUZ, CD; SÁVIO, FL. 2012. Métodos de agrupamento em estudo de divergência genética de pimentas. Horticultura Brasileira 30: 428-432.

GLAS, JJ; SCHIMMEL, BCJ; ALBA, JM; ESCOBAR-BRAVO, R; SCHUURINK, RC; KANT, MR. 2012. Plant glandular trichomes as targets for breeding or engineering of resistance to herbivores. International Journal of Molecular Sciences 13: 17077-17103.

GRUBER, K. 2017. The living library: Wild and heirloom plants are giving major crop varieties, and the global food system, a genetic makeover. Nature 544: 8-10.

IBGE - Instituto Brasileiro de Geografia e Estatística. 2017. Levantamento sistemático da produção Agrícola: pesquisa mensal de previsão e acompanhamento das safras agrícolas no ano civil. Rio de Janeiro: IBGE. 30 4: 1-84.

LUCATTI, AF; HEUSDEN, AW; VOS, RC; VISSER, RG; VOSMAN, B. 2013. Differences in insect resistance between tomato species endemic to the Galapagos Islands. $B M C$ Evolutionary Biology 13:1-12.

LUZ, JMQ; BITTAR, CA; OLIVEIRA, RC; NASCIMENTO, AR; NOGUEIRA, APO. 2016. Desempenho e divergência genética de genótipos de tomate para processamento industrial. Horticultura Brasileira 34: 483-490

MACIEL, GM; ALMEIDA, RS; PRISCILA, J; ANDALO, V; MARQUEZ, GR; SANTOS, NC; FINZI, RR. 2017. Mini tomato genotypes resistant to the silverleaf whitefly and to twospotted spider mites. Genetics and Molecular Research 16: 1-9.

MACIEL, GM; FERNANDES, MAR; MELO, OD; OLIVEIRA, CS. 2016. Potencial agronômico de híbridos de minitomate com hábito de crescimento determinado e indeterminado. Horticultura Brasileira 34: 144-148.

MACIEL, GM; FINZI, RR; CARVALHO, FJ; MARQUEZ, GR; CLEMENTE, AA. 2018b. Agronomic performance and genetic dissimilarity among cherry tomato genotypes. Horticultura Brasileira 36:158-163.

MACIEL, GM; MARQUEZ, GR; SILVA, EC; ANDALÓ, V; BELOTTI, IF. 2018a. Tomato genotypes with determinate growth and high acylsugar content presenting resistance to spider mite. Crop Breeding and Applied Biotechnology 18: 1-8.

MACIEL, GM; SILVA, EC. 2014. Proposta metodológica para quantificação de acilaçúcares em folíolos de tomateiro. Horticultura Brasileira 32: 174-177.

MACIEL, GM; SILVA, EC; FERNANDES, 
MAR. 2015. Ocorrência de nanismo em planta de tomateiro do tipo grape. Revista Caatinga 28: 259-264.

MALUF, WR; MACIEL, GM; GOMES, LAA; CARDOSO, MG; GONÇALVES, LD; SILVA, EC; KNAPP, M. 2010. Broad-spectrum arthropod resistance in hybrids between high and low-acylsugar tomato lines. Crop Science. 50: 439-450.

MANTEL, N. 1967. The detection of disease clustering and a generalized regression approach. Cancer Research 27: 209-220.

MATTEDI, AP; GUIMARÃES, MA; NICK, C; SILVA, DJH; PUIATTI, M; CARNEIRO, PCS. 2014. Genetic divergence of tomato subsamples. Revista Ceres 61: 70-76.

NEGREIROS, JRS; MIQUELONI, DP. 2013. Divergência genética de populações de Piper hispidinervum com base em caracteres morfoagronômicos. Pesquisa Agropecuária Tropical 43: 209-217.
NEIVA, IP; ANDRADE JÚNIOR, VC; MALUF, WR; OLIVEIRA, CM; MACIEL, GM. 2013. Role of allelochemicals and trichome density in the resistance of tomato to whitefly. Ciência e Agrotecnologia 37: 61-67.

PAIVA, CL; VIANA, AP; SANTOS, EA; SILVA, RNO; OLIVEIRA, EJ. 2014. Diversidade genética de espécies do gênero Passiflora com o uso da estratégia Ward-MLM. Revista Brasileira de Fruticultura 36: 381-390.

PRECZENHAK, AP; RESENDE, JTV; CHAGAS, RR; SILVA, PR; SCHWARZ, K; MORALES, RGF. 2014. Caracterização agronômica de genótipos de minitomate. Horticultura Brasileira 32: 348-356.

RESENDE, JTV; CARDOSO, MG; MALUF, WR; SANTOS, CD; GONÇALVES, LD; RESENDE, LV; NAVES, FO. 2002. Método colorimétrico para quantificação de acilaçúcar em genótipos de tomateiro. Ciência e Agrotecnologia 26: 1204-1208.

SILVA, AA; ANDRADE, MC; CARVALHO, RC;
NEIVA, IP; SANTOS, DC; MALUF, WR. 2016. Resistência à Helicoverpa armigera em genótipos de tomateiro obtidos do cruzamento de Solanum lycopersicum com Solanum galapagense. Pesquisa Agropecuária Brasileira 51: 801-808.

SILVA, AA; ANDRADE, MC; MALUF, WR; MORAES, JC; REZENDE, JF. 2017. Resistance of tomato plant genotypes with high foliar allelochemical contents to the leafminer Liriomyza trifolii. Arquivos do Instituto Biológico 84:1-6.

SINGH, D. 1981. The relative importance of characters affecting genetic divergence. The Indian Journal of Genetic and Plant Breeding 41: 237-245.

WESTON, PA; SNYDER, JC. 1990. Thumbtack biossay: a quick method of measuring plant resistance to twospotted spider mites (Acari: Tetranychidae). Journal of Economic Entomology 83: 501-504. 